\title{
REFLEKSJE DUSZPASTERSKIE
}

Książkę Osoba i czyn Kardynała Wojtyły czytałem dwa razy. Przy pierwszym czytaniu, mimo iż lektura jej dość trudna, przeżyłem ją jako przygodę. Rzeczywistość opisywaną przez Autora znałem ze studium filozofii i psychologii. Spotkałem się z nią przede wszystkim poprzez terminologię scholastyczną. Mimo to fascynowała mnie. Zainteresowanie nią rosło $\mathrm{w}$ miarę jak $\mathrm{w}$ myśleniu i w życiu ludzi współczesnych zwyżkowało znaczenie wartości personalistycznych. Poprzez definicję Boecjusza dostęp do osoby był niełatwy a ona sama trudno wyobrażalna. Praca Osoba $i$ czyn umożliwiła mi, że użyję terminologii Autora, ,wgląd i ogląd" osoby ujawniającej się w czynie. Był to właściwie wgląd we własną osobę i jej ogląd pod przewodnictwem Autora, jak sam o tym wspomina zresztą. Lektura książki stała się w ten sposób doświadczeniem osoby. Autor wprowadza nas krok za krokiem w rzeczywistość osoby. Oko jego jest lepiej od naszego obznajomione z jej rzeczywistością i dlatego widzi ostrzej i więcej od nas. Odkrywa skutkiem tego przed nami bogactwa osoby, jej wewnętrzną dynamikę i wzajemne zależności czyli jej życie, kształt jej istnienia. To właśnie stanowiło ową fascynującą przygodę.

W czasie lektury budziły się we mnie wątpliwości natury merytorycznej, które rodziły pytania o sprawdzalność opisu Autora, a tym samym i przeżywanego doświadczenia. W miarę jednak wchodzenia w lekture, słuszną wydawała się uwaga Autora, że głównym sprawdzianem jest doświadczenie siebie samego jako osoby.

W miarę czytania pracy Kardynała Wojtyły, jakkolwiek podkreślił On filozoficzny charakter swojej rozprawy, pytałem o konsekwencje, jakie wynikają z niej dla duszpasterstwa, w którym, szczególnie po II Soborze Watykańskim, wzrasta wrażliwość na wartości osobowe. Pytanie 
takie postawiłem między innymi w czasie sympozjum, jakie na temat książki Osoba i czyn odbyło się na KUL.

Zachęcony przez Autora do szukania odpowiedzi na to pytanie, zabrałem się powtórnie do czytania książki, tym razem bardziej analitycznego. Lecz i po drugim czytaniu odpowiedź jest niełatwa. Potwierdziło ono jednak przekonanie, że książka zawiera wiele treści personalistycznych, które powinny wejść do dzisiejszego duszpasterstwa, wzbogacająe je i pomagając mu. Trudność odpowiedzi polega między innymi na tym, że studium Osoba $i$ czyn rozpatruje osobę w innym aspekcie niż duszpasterstwo. Myślę jednak, że przynajmniej częściową odpowiedź można znaleźć na dwóch płaszczyznach: doświadczenia osobistego czytelnika i w niektórych wypowiedziach samego Autora.

1. Czytelnik, prowadzony przez Autora, doświadczy najpierw istnienia osoby, z którą stale obcuje. Zrozumie dalej, że różni się ona od wszystkiego co ją otacza - transcendencją wsobną, która wyraża się przede wszystkim w samowiedzy i w samostanowieniu. Dostrzeże dynamiczna jedność sprawczości i podmiotowości osoby. Zauważy związek osoby z rzeczywistością poprzez prawdę i dobro, a równocześnie jej nadrzędność w stosunku do niej poprzez zdolność rozpoznania prawdy, szczególnie prawdziwego dobra. Przeżyje prawdopodobnie jako wielkie wzruszenie stwierdzenie, że od niego samego zależy rozwój lub niedorozwój osoby. Spełnia się ona bowiem i rośnie przez czyny prawdziwie dobre, a nie spełnia się i niejako zatrzymuje w rozwoju przez czyn zły. Trafi mu, jak sądzę, do przekonania uwaga Autora, że powinność, odpowiedzialność, które stanowią osnowę życia duchowego człowieka, a przez które widać niejako przyporządkowanie osoby do prawdy, są przejawem duchowości osoby. Musi im dlatego odpowiadać realna immanencja pierwiastka duchowego w człowieku. Znajdzie też w tej pracy odczutą przez siebie prawdę, że osoba podporządkowuje sobie w czynie siły popędowe i uczuciowe. W ten sposób powstaje przez osobę jedność wszystkiego, czym człowiek jest i co posiada, jedność: człowiek.

Takie doświadczenia pozwalające przeżyć syntetyzującą i centralną rolę osoby w człowieku pomogą duszpasterzowi lepiej zrozumieć wagę tendencji personalistycznych we współczesnym życiu i w duszpasterstwie. Skłonią go one prawdopodobnie także do refleksji nad jego dotychczasową pracą duszpasterską. Sądzę bowiem, że duszpasterz, który doświadczył wielkości osoby i jej roli decydującej o wartości człowieka, nie będzie mógł zapomnieć o niej w posłudze duszpasterskiej.

Myślę, że obok doświadczenia osoby, jeszcze i inne stanie się udziałem duszpasterza. Przekona się on, że rzeczywistość duchową można przedstawić językiem zrozumiałym dla dzisiejszego człowieka, którego 
umysłowość kształtuje się $\mathrm{w}$ oparciu o zjawisko. Takim zrozumiałym językiem jest opis, który uprzystępnia „ogląd i wgląd”.

2. W trakcie swojej pracy Autor dotyka szeregu zagadnień egzystencjalnych, których wyjaśnienie współczesnemu człowiekowi sprawia duszpasterzowi sporą trudność. W czasie studiów teologicznych przyswoił on sobie bowiem podejście do nich, które nie znajduje zrozumienia. Są to takie zagadnienia jak: sumienie, moralność, wolność, szczęście, szczęście wieczne, duchowość człowieka, stosunek duszy do ciała. Autor zaledwie ich dotyka, gdyż, jak to kilkakrotnie podkreśla, wykraczają one poza przedmiot Jego studium. Szersze rozpracowanie uwag Autora mogłoby bardzo pomóc duszpasterzowi do lepszego zrozumienia tych zagadnień, a z kolei ułatwić mu udzielenie wyjaśnień i odpowiedzi dzisiejszemu człowiekowi. Kapłan obarczony wieloma obowiązkami duszpasterskimi nie jest w stanie rozpracować samodzielnie tych krótkich refleksji Autora. Potrzebuje pomocy fachowca. Dlatego sądzę, że trzeba, by w uzupełnieniu sympozjum, jakie odbyło się nad pracą Księdza Kardynała Wojtyły Osoba $i$ cayn na KUL, a które zajmowało się głównie stroną merytoryczną pracy, zorganizowane zostało sympozjum złożone $\mathrm{z}$ teologów, głównie moralistów, pastoralistów i katechetów, które by podjęło aspekty pastoralne wspomnianych zagadnien.

Może zresztą Autor, który książkami swymi chce służyć Ludowi Bożemu, sam kiedyś wróci jeszcze do tych zagadnień.

Myślę także, że duszpasterze i katecheci byliby bardzo wdzięczni, gdyby udało się, może na drodze wymiany zdań, przedstawione przez Autora ujęcie osoby, przede wszystkim zaś te momenty, które pokazują strukturę jej istnienia i stawania się, powiedzieć w języku mniej skondensowanym i bliższym sposobu myślenia i mówienia młodzieży. 